\title{
RP-HPLC METHOD DEVELOPMENT AND VALIDATION OF MACITENTAN WITH ITS KNOWN AND UNKNOWN DEGRADATION IMPURITIES IN ITS TABLET DOSAGE FORM
}

\author{
JAHANVEE K. TRIVEDI ${ }^{*}{ }^{*}$, CHIRAG J. PATEL ${ }^{b}$, M. M. PATEL ${ }^{c}$ \\ a,bDepartment of Pharmaceutical Quality Assurance, Shree Swaminarayan Sanskar Pharmacy College, Gandhinagar, Gujarat, India, cShree \\ Swaminarayan Sanskar Pharmacy College, Gandhinagar, Gujarat, India \\ Email: jahanveetrivedi13@gmail.com \\ Received: 24 Mar 2018, Revised and Accepted: 02 Jul 2018
}

\section{ABSTRACT}

Objective: To develop and validate macitentan with its known and unknown degradation impurities in its tablet dosage form.

Methods: The RP-HPLC method for macitentan and its impurities was developed and three potential degradation impurities MCA-02, MCA-01 and degradation impurity and $\mathrm{N}$-propyl derivative and $\mathrm{N}-\mathrm{N}$ dimethyl derivative process impurities were separated. Chromatographic separation was achieved within $70 \mathrm{~min}$ on Inertsil C8 $\left(250^{*} 4.6 \mathrm{~mm}, 5 \mu \mathrm{m}\right)$ column, Using mobile phase A [Ammonium acetate (ph 4.5 adjusted with glacial acetic acid)] and mobile phase B acetonitrile in gradient elution. Other hplc parameter which was optimized flow rate $1.5 \mathrm{ml} / \mathrm{min}$, detection wavelength $266 \mathrm{~nm}$, column oven temperature $30^{\circ} \mathrm{C}$ and injection volume $20 \mu \mathrm{l}$. macitentan was subjected to forced degradation also known as stress testing. It was validated as per ICH guidelines.

Results: The drug showed extensive degradation in acidic and basic conditions, a slight degradation in oxidative condition. The developed method was statistically validated for linearity $(0.45-2.25 \mathrm{ppm})$. The result of precision $(\% \mathrm{RSD}<5)$, robustness, $\operatorname{LOD}(0.15 \mathrm{ppm})$ and $\mathrm{LOQ}(0.45 \mathrm{ppm})$ are well within limits.\% Recovery at LOQ, 50\%, 100\% and 150\% was found to be within limit 80-120\%.

Conclusion: RP-HPLC method was successfully developed with satisfactory separation of macitentan and its impurities. The proposed method was found to be specific, accurate, precise and robust can be used for estimation of macitentan and its impurities and can be successfully employed in the routine analysis of macitentan.

Keywords: RP-HPLC, Macitentan, Forced Degradation

(C) 2018 The Authors. Published by Innovare Academic Sciences Pvt Ltd. This is an open access article under the CC BY license (http://creativecommons.org/licenses/by/4.0/) DOI: http://dx.doi.org/10.22159/ijap.2018v10i5.26211

\section{INTRODUCTION}

Macitentan is chemically a $\{[5$-(4-bromophenyl)-6- $\{2-[$ [5-bromopyrimidin-2-yl)oxy]ethoxy\}pyrimidin-4-yl]sulfamoyl\}(propyl) amine) with molecular weight of $588.273 \mathrm{~g} / \mathrm{mol}$ [1].

Macitentan blocks the ET1-dependent rise in intracellular calcium by inhibiting the binding of ET-1 to ET receptors. Blocking of the ETA receptor subtype seems to be of more importance in the treatment of PAH than blocking of ETB, likely because there are higher numbers of ETA receptors than ETB receptors in pulmonary arterial smooth muscle cells [2-4].

A survey of literature revealed that RP-HPLC, first order Derivative UV Spectroscopy, and stability indicating analytical methods have been reported for macitentan. On literature survey, it was found that there are few RP-HPLC analytical methods available, but in my work impurities to be estimated are other than the reported one. Hence it was thought worthwhile to develop a method for estimation of impurities and related substance in macitentan using HPLC [5-9].

Therefore, it was of thought interest to develop precise, accurate, sensitive, selective chromatographic method for estimation of macitentan in Tablet dosage form which will provide valuable information that can be used to assess the inherent stability of the drug under various stressed conditions, eventually to improve formulation and manufacturing process. The aim of work was to carry out RP-HPLC method development and validation for macitentan tablet dosage form [10-12].

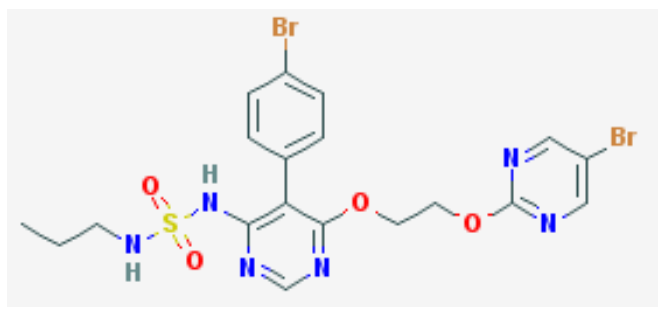

Fig. 1: Structure of macitentan

\begin{abstract}
MATERIALS AND METHODS
In the present research work, an attempt was made to develop and validate macitentan tablet dosage form with its Known and unknown Degradation Impurities with RP-HPLC method. acetonitrile, methanol, ammonium acetate, potassium hydrogen Phosphate, hydrochloric acid, sodium hydroxide, hydrogen peroxide, glacial acetic acid and phosphoric Acid were produce from Merck. The sample of Macitentan API, Tablets and impurities were kindly gifted by ZYDUS CADILA HEALTH CARE, Moraiya, Ahmedabad [13].
\end{abstract}

Table 1: List of Impurities with their specification

\begin{tabular}{lll}
\hline S. No. & Impurity & Acceptance criteria \\
\hline 1 & (MCA-01) & Not more than $0.15 \%$ \\
2 & (MCA-02) & Not more than $0.15 \%$ \\
3 & (Degradation) & Not more than $0.15 \%$ \\
4 & (N-propyl derivative) & Not more than $0.10 \%$ \\
5 & (N-N Dimethyl derivative) & Not more than $0.15 \%$ \\
\hline
\end{tabular}




\section{Equipment}

The analysis was performed on HPLC Agilent technologies 1200 series, fitted with a gradient pump photodiode array detector and rheodyne injector with $20 \mu \mathrm{l}$ loop volume. Inertsil C8 $(250 \mathrm{~mm} * 4.6 \mathrm{~mm}) 5 \mu \mathrm{m})$ column which is maintained at $30^{\circ} \mathrm{C}$ temperature. Chem-station software was applied for data collecting and processing

\section{Preparation of mobile phase}

Prepare a Mobile phase A [Ammonium acetate (ph 4.5 adjusted with glacial acetic acid)] and Mobile phase B Acetonitrile in gradient elution. A buffer was sonicated for 5 min (minute) for degassing and filtered through $0.45 \mu$ Millipore filter.

\section{Diluent}

The drug was dissolved in acetonitrile.

\section{Preparation of standard stock solution (200 ppm)}

Transfer an accurately weighed quantity of about $20 \mathrm{mg}$ of Macitentan working standard into $100 \mathrm{ml}$ of volumetric flask. Add about $50 \mathrm{ml}$ of diluent and sonicate to dissolve. Make the volume up to mark with diluent and mix.

\section{Preparation of standard solution (10 ppm)}

Take $5 \mathrm{ml}$ from std. A stock solution was transferred into the $100 \mathrm{ml}$ volumetric flask and then diluted with the diluents.

\section{Preparation of impurities solution: (10 ppm)}

MCA-01: Weigh $1.012 \mathrm{mg}$ of MCA-01 dissolve in $10 \mathrm{ml}$ of diluent 2. Take $1 \mathrm{ml}$ of it and dissolve in $10 \mathrm{ml}$ diluents and mix well.

MCA-02: Weigh $1.005 \mathrm{mg}$ of MCA-02 dissolve in $10 \mathrm{ml}$ of diluent 2. Take $1 \mathrm{ml}$ of it and dissolve in $10 \mathrm{ml}$ diluents and mix well.

Degradation impurity: Weigh $1.003 \mathrm{mg}$ of degradation impurity dissolve in $10 \mathrm{ml}$ of diluent 2 . Take $1 \mathrm{ml}$ of it and dissolve in $10 \mathrm{ml}$ diluents and mix well.
N-N Dimethyl derivative impurity: Weigh $1.042 \mathrm{mg}$ of N-N Dimethyl derivative impurity dissolve in $10 \mathrm{ml}$ of diluent 2 . Take $1 \mathrm{ml}$ of it and dissolve in $10 \mathrm{ml}$ diluents and mix well.

N-propyl derivative: Weigh $1.023 \mathrm{mg}$ of N-propyl derivative impurity dissolve in $10 \mathrm{ml}$ of diluent 2 . Take $1 \mathrm{ml}$ of it and dissolve in $10 \mathrm{ml}$ diluents and mix well.

(Diluent 2: 0.05\% v/v HCL in ACN)

Spiked impurity mixture: (Specification limit of impurities $=0.15 \%$ )

Take $1 \mathrm{ml}$ of the stock solution of standard, $1 \mathrm{ml}$ of MCA-01 Stock solution, $1 \mathrm{ml}$ of MCA- 02 solution, $1 \mathrm{ml}$ of Degradation impurity solution, $1 \mathrm{ml}$ of $\mathrm{N}-\mathrm{N}$ Dimethyl derivative impurity solution, $1 \mathrm{ml}$ of N Propyl derivative impurity solution dilute up to $20 \mathrm{ml}$ with ACN. Filter solution with $0.45 \mu \mathrm{m}$ PVDF Filter.

\section{As such sample preparation: (1000 ppm)}

\section{[label claim: $10 \mathrm{mg}$ ]}

The average of 10 Tablet was determined and grounded in a mortar. Weigh and transfer crush tablet equivalent to $50 \mathrm{mg}(182.3 \mathrm{mg})$ into $50 \mathrm{ml}$ of volumetric flask. Add $30 \mathrm{ml}$ diluent (ACN) and sonicate for $45 \mathrm{~min}$ and makeup to $50 \mathrm{ml}$ with diluents Mix well. Filter with 0.45 $\mu \mathrm{m}$ PVDF Filter.

\section{Chromatographic conditions}

Inertsil C8 $(250 * 4.6 \mathrm{~mm}, 5 \mu \mathrm{m}$ column was used as the stationary phase. Using mobile phase A [Ammonium acetate (ph 4.5 adjusted with glacial acetic acid)] and mobile phase B Acetonitrile in gradient elution It was filtered through $0.45 \mu$ (micron) membrane filter and degassed. The mobile phase was pumped at $1.5 \mathrm{ml} / \mathrm{min}$. The eluents were monitored at $266 \mathrm{~nm}$. The injection volumes of sample and standard were $20 \mu \mathrm{l}$ (microliter). Total run time is $70 \mathrm{~min}$.

Table 2: Gradient program

\begin{tabular}{|c|c|c|}
\hline Time & MP A & MP B \\
\hline 0 & 66 & 34 \\
\hline 5 & 66 & 34 \\
\hline 15 & 60 & 40 \\
\hline 30 & 50 & 50 \\
\hline 50 & 40 & 60 \\
\hline 60 & 25 & 75 \\
\hline 62 & 66 & 34 \\
\hline 70 & 66 & 34 \\
\hline
\end{tabular}

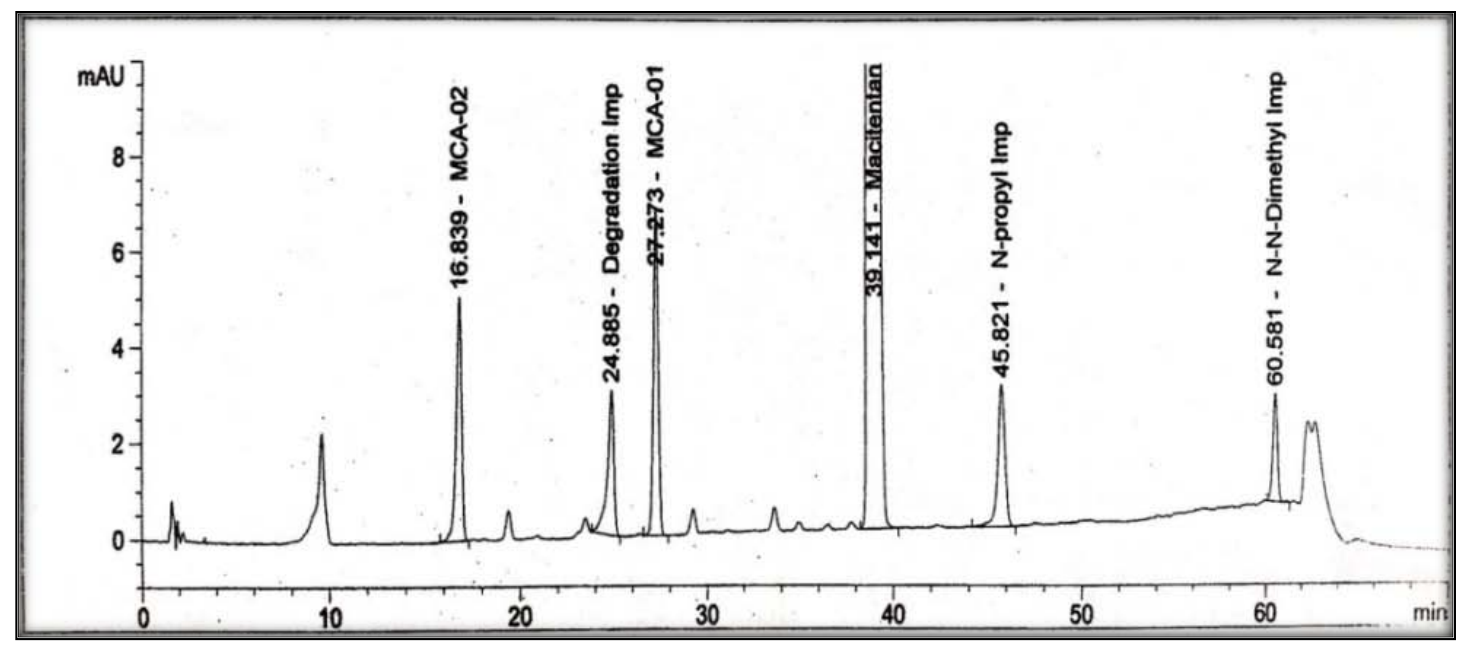

Fig. 2: Chromatogram of macitentan with its impurities 
The developed Method was validated for linearity, precision, accuracy, robustness and is applied for forced degradation studies as per the ICH guidelines.

\section{RESULTS AND DISCUSSION}

\section{Method development}

ICH prescribed stress conditions such as acidic, basic and oxidative stresses were carried out.

\section{Acid degradation}

Sample preparation

The average of 10 Tablet was determined and grounded in a mortar. An accurately weighed the amount of powder equivalent to $10 \mathrm{mg}$ of macitentan $(152.5 \mathrm{mg})$ sample dissolve in $10 \mathrm{ml}$ of diluent (ACN) sonicate for $30 \mathrm{~min}$ then add $1 \mathrm{ml}$ of $5 \mathrm{~N} \mathrm{HCL}$ and heat at $80^{\circ} \mathrm{C}$ in water bath for $1 \mathrm{~h}$. Then cool it at RT and neutralize it with $1 \mathrm{ml}$ of 5 $\mathrm{M} \mathrm{NaOH}$. Makeup to volume $25 \mathrm{ml}$ with Diluent. Filter it.

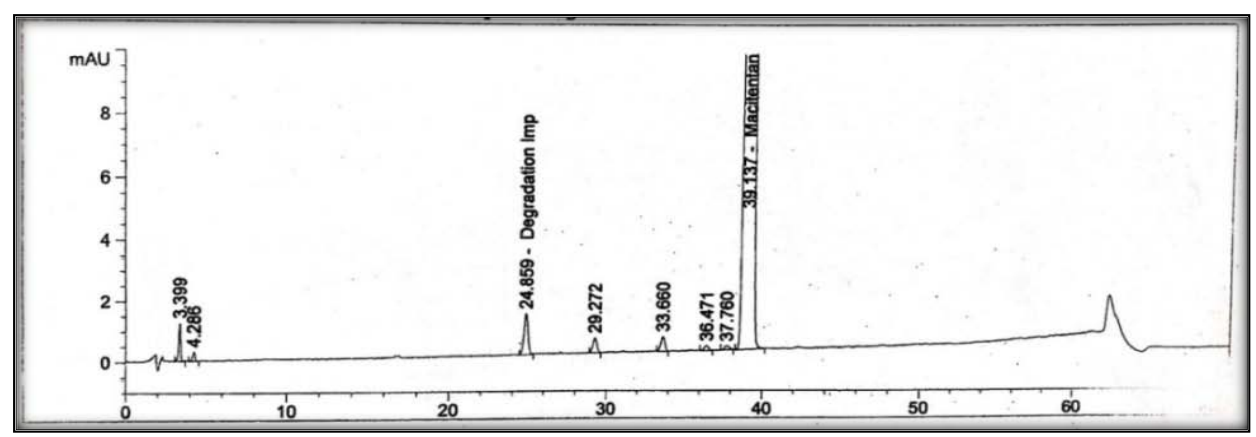

Fig. 3: Acid degradation for macitentan

\section{Base degradation}

\section{Preparation of sample}

The average of 10 Tablet was determined and grounded in a mortar. An accurately weighed the amount of powder equivalent to $10 \mathrm{mg}$ of macitentan $(152.6 \mathrm{mg})$ sample dissolve in $10 \mathrm{ml}$ of diluent (ACN) sonicate for $30 \mathrm{~min}$ then add $1 \mathrm{ml}$ of $5 \mathrm{M} \mathrm{NaOH}$ and heat at $80^{\circ} \mathrm{C}$ in a water bath for $1 \mathrm{~h}$. then cool it at RT and neutralize it with $1 \mathrm{ml}$ of $5 \mathrm{~N} \mathrm{HCL}$. Make up to volume $25 \mathrm{ml}$ with Diluent. Filter it.

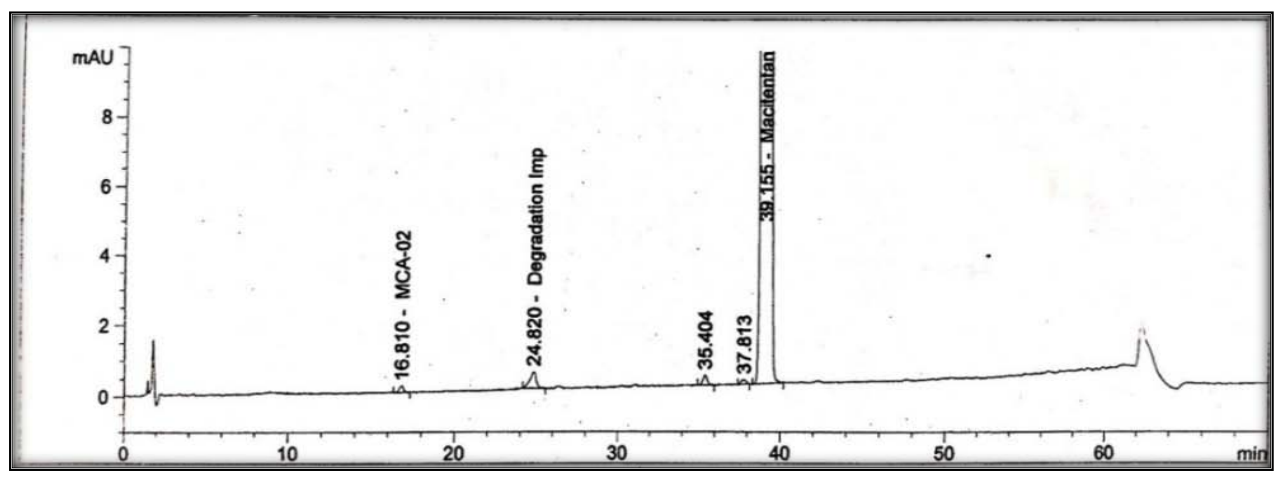

Fig. 4: Base degradation for macitentan

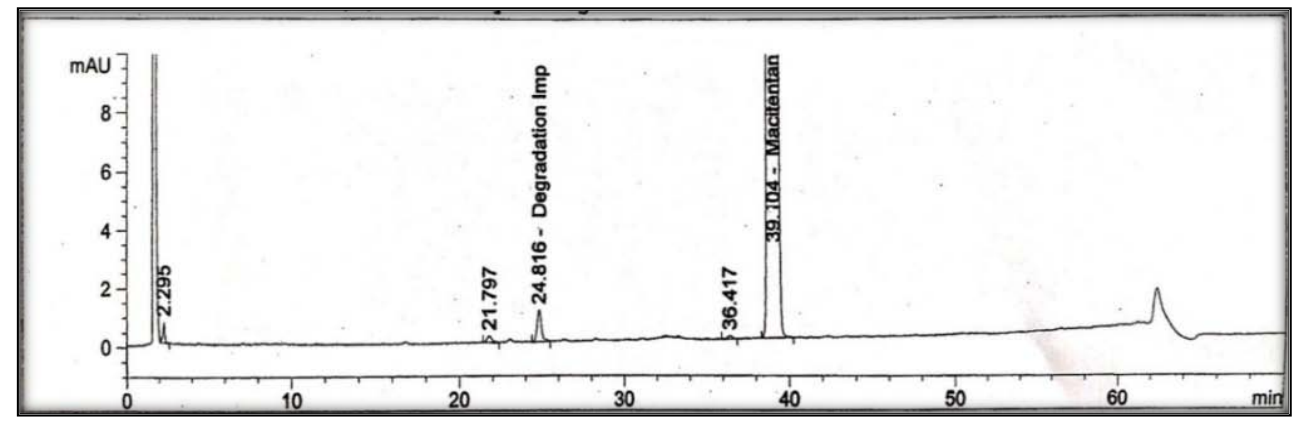

Fig. 5: Peroxide degradation for macitentan

Table 3: Degradation summary

\begin{tabular}{llll}
\hline Type & Solution & Area & \%Degradation \\
\hline As Such & macitentan & 159223 & - \\
Acid Degradation & macitentan & 136124 & $14.50 \%$ \\
Base Degradation & macitentan & 141223 & $11.30 \%$ \\
Peroxide Degradation & macitentan & 150013 & $5.78 \%$ \\
\hline
\end{tabular}




\section{Peroxide degradation}

\section{Preparation of sample}

$152.5 \mathrm{mg}$ sample dissolve in $10 \mathrm{ml}$ with diluents sonicate for $30 \mathrm{~min}$ then add $1 \mathrm{ml}$ of $10 \% \mathrm{H}_{2} \mathrm{O}_{2}$ and heat at $80^{\circ} \mathrm{C}$ in a water bath for $1 \mathrm{~h}$ then cool the sample at RT and make up a sample with Diluent. Filter it.

\section{Method validation}

The described method has been validated which include parameters like linearity, accuracy, precision, robustness, LOD (limit of detection) and LOQ (limit of quantification).

\section{Linearity}

The linearity of this method was evaluated by linear regression analysis and calculated by a least square method and studied by preparing stock solutions of MCA-01, MCA-02 and Degradation impurities at different concentration levels.

The calibration curve showed good linearity in the range of 0.45 $2.25 \mu \mathrm{g} / \mathrm{ml}$. Generate linearity plot of area versus percentage of concentration. Linearity curve it should be more than 0.998 that shows linear detector response. The results are given in table 4 .

Table 4: Linearity data for MCA-02, MCA-01 and degradation impurity

\begin{tabular}{|c|c|c|}
\hline Drug & Conc* $^{*}(\mu \mathrm{g} / \mathrm{ml})$ & Area \\
\hline \multirow[t]{5}{*}{ MCA-02 } & 0.45 & 11030 \\
\hline & 0.75 & 18032 \\
\hline & 1.5 & 36568 \\
\hline & 1.8 & 43723 \\
\hline & 2.25 & 55123 \\
\hline \multirow[t]{5}{*}{ MCA-01 } & 0.45 & 15218 \\
\hline & 0.75 & 25003 \\
\hline & 1.5 & 50423 \\
\hline & 1.8 & 61517 \\
\hline & 2.25 & 73930 \\
\hline \multirow[t]{5}{*}{ Degradation Impurity } & 0.45 & 9718 \\
\hline & 0.75 & 16131 \\
\hline & 1.5 & 33001 \\
\hline & 1.8 & 40051 \\
\hline & 2.25 & 51358 \\
\hline
\end{tabular}

Conc*-concentration

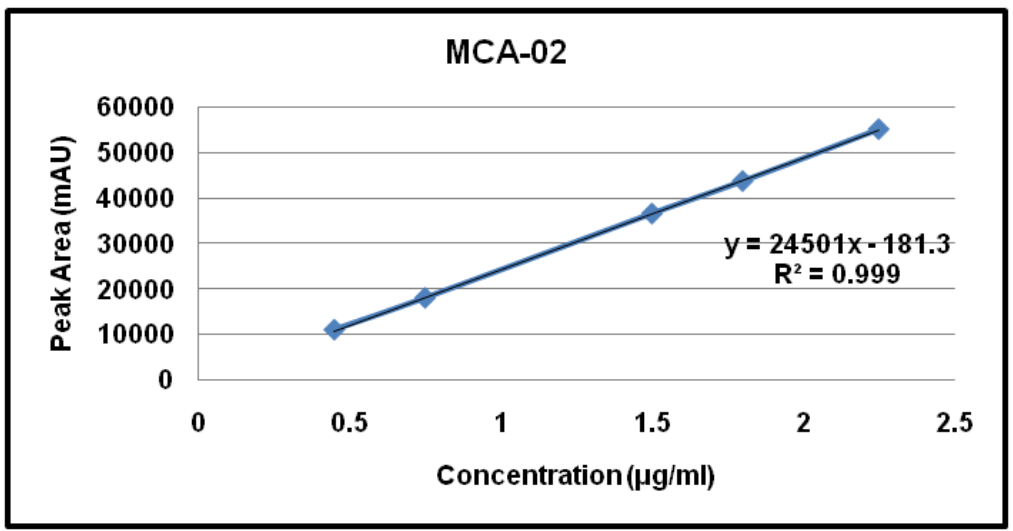

Fig. 6: Calibration curve of MCA-02

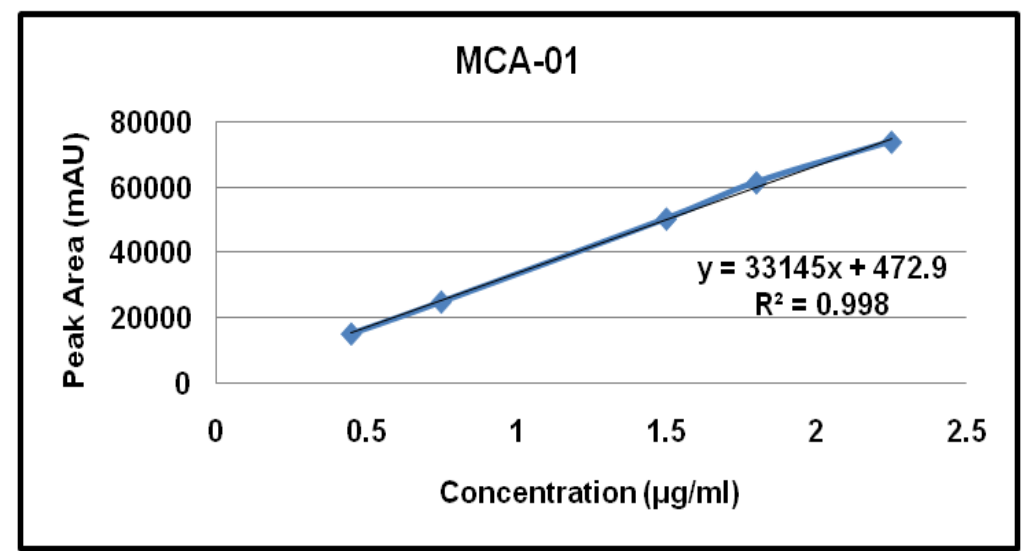

Fig. 7: Calibration curve of MCA-01 


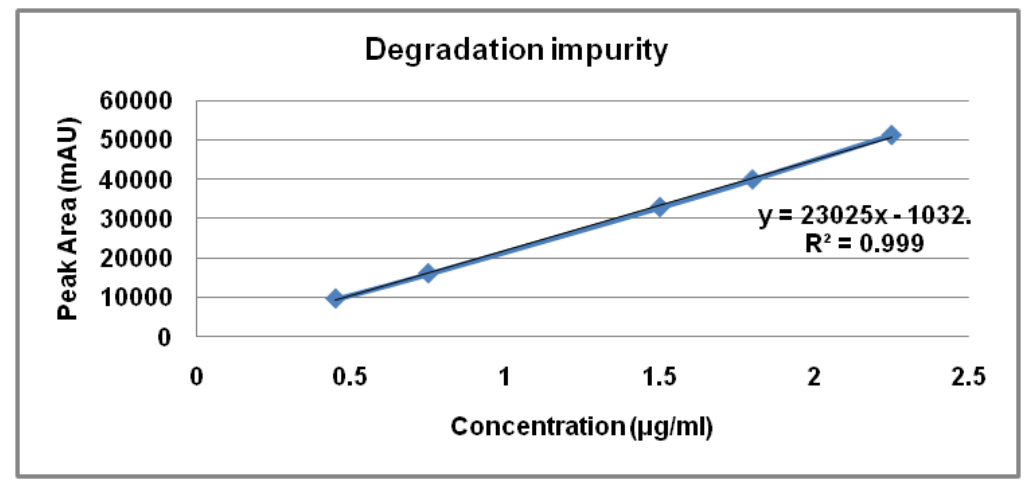

Fig. 8: Calibration curve of degradation impurity

Table 5: Recovery data of MCA-02

\begin{tabular}{llllll}
\hline $\begin{array}{l}\text { Conc } \\
\text { level }\end{array}$ & Amount added & Area observed & $\begin{array}{l}\text { Amount } \\
\text { recovered }\end{array}$ & $\begin{array}{l}\text { \% } \\
\text { recovery }\end{array}$ & $\begin{array}{l}\text { \% Mean } \\
\text { recovery } \pm \text { SD }\end{array}$ \\
\hline LOQ & 0.45 & 11123 & 0.457 & 101.55 & \\
$30 \%$ & 0.45 & 11345 & 0.466 & 103.55 & $102.51 \pm 1.00$ \\
& 0.45 & 11234 & 0.461 & 102.44 & $97.37 \pm 0.33$ \\
$50 \%$ & 0.75 & 18138 & 0.745 & 99.33 & $97.77 \pm 0.381$ \\
& 0.75 & 18098 & 0.743 & 99.73 & \\
$100 \%$ & 0.75 & 18212 & 0.748 & 97.33 & \\
& 1.5 & 35735 & 1.46 & 98.00 & 9.34 \\
$150 \%$ & 1.5 & 35918 & 1.47 & 98.00 & $9.40 \pm 0.254$ \\
& 1.5 & 35824 & 1.47 & 99.55 & \\
\end{tabular}

$\mathrm{SD}^{*}$-Standard deviation, RSD*-relative standard deviation, number of experiments (n)-3

Table 6: Recovery data of MCA-01

\begin{tabular}{|c|c|c|c|c|c|c|}
\hline $\begin{array}{l}\text { Conc } \\
\text { level }\end{array}$ & Amount added & Area observed & Amount recovered & $\begin{array}{l}\% \\
\text { recovery }\end{array}$ & $\%$ Mean recovery \pm SD & \%RSD \\
\hline & 0.45 & 16212 & 0.472 & 104.8 & $105.46 \pm 1.15$ & \\
\hline LOQ & 0.45 & 16524 & 0.481 & 106.8 & & 1.09 \\
\hline \multirow[t]{2}{*}{$30 \%$} & 0.45 & 16224 & 0.472 & 104.8 & & \\
\hline & 0.75 & 25233 & 0.735 & 98 & $98.00 \pm 0.230$ & \\
\hline \multirow[t]{3}{*}{$50 \%$} & 0.75 & 25148 & 0.732 & 97.6 & & 0.24 \\
\hline & 0.75 & 25255 & 0.735 & 98 & & \\
\hline & 1.5 & 50021 & 1.457 & 97.13 & $97.00 \pm 0.231$ & \\
\hline \multirow[t]{3}{*}{$100 \%$} & 1.5 & 49812 & 1.451 & 96.73 & & 0.24 \\
\hline & 1.5 & 50013 & 1.457 & 97.13 & & \\
\hline & 2.25 & 74334 & 2.165 & 96.22 & $96.01 \pm 0.045$ & \\
\hline \multirow[t]{2}{*}{$150 \%$} & 2.25 & 74331 & 2.164 & 96.17 & & 0.05 \\
\hline & 2.25 & 74282 & 2.163 & 96.13 & & \\
\hline
\end{tabular}

Number of experiments (n)-3, SD*-Standard deviation, RSD*-Relative Standard deviation

Table 7: Recovery data of degradation impurity

\begin{tabular}{|c|c|c|c|c|c|c|}
\hline $\begin{array}{l}\text { Conc } \\
\text { level }\end{array}$ & Amount added & Area observed & Amount recovered & \% recovery & $\begin{array}{l}\% \text { Mean } \\
\text { recovery } \pm S^{*}\end{array}$ & \%RSD \\
\hline & 0.45 & 9118 & 0.411 & 91.33 & $91.34 \pm 1.110$ & \\
\hline LOQ & 0.45 & 9013 & 0.406 & 90.22 & & 1.22 \\
\hline \multirow[t]{2}{*}{$30 \%$} & 0.45 & 9228 & 0.416 & 92.44 & & \\
\hline & 0.75 & 15830 & 0.714 & 95.20 & $95.82 \pm 0.669$ & \\
\hline \multirow[t]{3}{*}{$50 \%$} & 0.75 & 15911 & 0.718 & 95.73 & & 0.70 \\
\hline & 0.75 & 16045 & 0.724 & 96.53 & & \\
\hline & 1.5 & 33586 & 1.514 & 100.9 & $101.00 \pm 0.655$ & \\
\hline \multirow[t]{3}{*}{$100 \%$} & 1.5 & 33816 & 1.526 & 101.7 & & 0.64 \\
\hline & 1.5 & 33404 & 1.507 & 100.4 & & \\
\hline & 2.25 & 51151 & 2.309 & 102.6 & $102.56 \pm 0.251$ & \\
\hline \multirow[t]{2}{*}{$150 \%$} & 2.25 & 50998 & 2.302 & 102.3 & & 0.24 \\
\hline & 2.25 & 51258 & 2.313 & 102.8 & & \\
\hline
\end{tabular}

$\mathrm{SD}^{*}$-Standard deviation, Conc*-concentration, RSD*-Relative Standard deviation, Number of experiments (n)-3 


\section{Accuracy}

The accuracy of the method was determined at LOQ (30\%), 50\%, $100 \%$ and $150 \%$ by calculating recovery of Impurities in the solution. Each solution was injected in triplicate and the \% recovery was calculated. Recovery (individually) at each level is between 91$106 \%$. RSD of \% recovery is not more than 5 . The results are given in table 5-7.

\section{Limit of detection (LOD) and limit of quantification (LOQ)}

According to the ICH recommendation, the approach based on the standard deviation (SD) of the response and slope was a use of the determining the LOD and $L O Q$ values.
The LOD and LOQ were found to be $0.15 \mu \mathrm{g} / \mathrm{ml}$ and $0.45 \mu \mathrm{g} / \mathrm{ml}$ for MCA-01, MCA-02 and Degradation impurity estimated by using the $\mathrm{S} / \mathrm{N}$ ratio. The low values of LOD and LOQ illustrate that the developed method was sensitive, accurate and precise as it can be detected and quantify with very low concentration.

\section{Acceptance criteria: LOQ}

It is estimated the progressive lower concentration of impurity until a signal to noise $(\mathrm{S} / \mathrm{N})$ ratio remains greater than 10 .

\section{LOD}

It is estimated by injecting the diluted concentration until the peak of impurity is able to detect. The results are given in table 8 .

Table 8: S/N Ratio for LOD and LOQ of impurity

\begin{tabular}{lll}
\hline Name of impurity & LOD (S/N Ratio) & LOQ (S/N Ratio) \\
\hline MCA-02 & 8.17 & 58.1 \\
MCA-01 & 5.92 & 48.5 \\
Degradation Impurity & 6.17 & 65.4 \\
\hline
\end{tabular}

LOD-Limit of detection, LOQ-Limit of quantification

\section{Precision}

\section{Repeatability}

For Repeatability sample containing all impurities at $100 \%$ level injected for six times and for the intermediate precision sample containing all impurities at 50\%, 100\%, 150\% level injected for Intraday precision and Interday precision it is injected in 3 sets. Sample spiked with all known impurities at $100 \%$ level injected six times. All impurity peak area calculated for RSD. \% RSD is not more than 5 . The results are given in table 9.

Table 9: Repeatability data of MCA-02, MCA-01, degradation impurity

\begin{tabular}{lllll}
\hline S. No. & $\begin{array}{l}\text { Concentration PPM } \\
\text { level) }\end{array}$ & $\mathbf{1 0 0} \%$ & Peak area & Degradation impurity \\
\cline { 2 - 5 } & 1.5 & MCA-02 & MCA-01 & 32378 \\
\hline 1 & 1.5 & 35740 & 50381 & 31318 \\
2 & 1.5 & 35948 & 50581 & 32484 \\
3 & 1.5 & 34998 & 49380 & 32980 \\
4 & 1.5 & 36141 & 51008 & 32035 \\
5 & 1.5 & 35889 & 50451 & 32123 \\
6 & 36030 & 50661 & $32220 \pm 553.08$ \\
$\%$ Mean recovery \pm SD $^{*}$ & $35791 \pm 411.17$ & $50410 \pm 550.13$ & 1.72 \\
\hline
\end{tabular}

SD*-Standard deviation, RSD*-Relative standard deviation, Number of experiments (n)-6, Conc*-concentration

\section{Intraday precision}

Intraday precision was performed by injecting stock impurities preparations two times (Morning and Evening) on the day by maintaining the optimized chromatographic conditions and calculate \% relative standard deviation of retention time and peak areas for macitentan. All impurity area calculated for RSD for morning and evening. \% RSD is not more than 5. so method is precise. The results are given in table 10,11, and 12.

Table 10: Intraday precision of MCA-02

\begin{tabular}{|c|c|c|c|c|c|}
\hline \multicolumn{6}{|c|}{50 \% level } \\
\hline Set & Level & Morning & Evening & mean $\pm \mathrm{SD}^{*}$ & RSD \\
\hline 1 & $50 \%$ & 20432 & 20124 & $20278 \pm 217.98$ & 1.07 \\
\hline 2 & $50 \%$ & 20213 & 20598 & $20406 \pm 272.24$ & 1.33 \\
\hline 3 & $50 \%$ & 20513 & 20188 & $20351 \pm 229.80$ & 1.13 \\
\hline \multicolumn{6}{|c|}{$100 \%$ level } \\
\hline Set & Level & Morning & Evening & mean $\pm \mathrm{SD}^{*}$ & RSD \\
\hline 1 & $100 \%$ & 36981 & 35991 & $36486 \pm 700.03$ & 1.92 \\
\hline 2 & $100 \%$ & 36607 & 36033 & $36320 \pm 405.87$ & 1.12 \\
\hline 3 & $100 \%$ & 36108 & 35997 & $36053 \pm 78.48$ & 0.22 \\
\hline \multicolumn{6}{|c|}{$150 \%$ level } \\
\hline Set & Level & Morning & Evening & mean $\pm \mathrm{SD}^{*}$ & RSD \\
\hline 1 & $150 \%$ & 55814 & 55125 & $55470 \pm 487.19$ & 0.88 \\
\hline 2 & $150 \%$ & 56124 & 55899 & $56012 \pm 159.09$ & 0.28 \\
\hline 3 & $150 \%$ & 55754 & 55160 & $55457 \pm 420.02$ & 0.76 \\
\hline
\end{tabular}

SD*-Standard deviation, RSD*-Relative Standard deviation, Number of experiments (n)-3 
Table 11: Intraday precision of MCA-01

\begin{tabular}{|c|c|c|c|c|c|}
\hline \multicolumn{6}{|c|}{$50 \%$ level } \\
\hline Set & Level & Morning & Evening & mean $\pm \mathrm{SD}^{*}$ & RSD \\
\hline 1 & $50 \%$ & 26013 & 25981 & $25997 \pm 22.62$ & 0.09 \\
\hline 2 & $50 \%$ & 26312 & 26121 & $26217 \pm 135.05$ & 0.52 \\
\hline 3 & $50 \%$ & 26567 & 26056 & $26312 \pm 361.33$ & 1.37 \\
\hline \multicolumn{6}{|c|}{$100 \%$ level } \\
\hline Set & Level & Morning & Evening & mean $\pm S D^{*}$ & RSD \\
\hline 1 & $100 \%$ & 52254 & 51789 & $52022 \pm 328.80$ & 0.63 \\
\hline 2 & $100 \%$ & 52312 & 52013 & $52163 \pm 211.42$ & 0.41 \\
\hline 3 & $100 \%$ & 52159 & 51936 & $52048 \pm 157.68$ & 0.30 \\
\hline \multicolumn{6}{|c|}{$150 \%$ level } \\
\hline Set & Level & Morning & Evening & mean $\pm S^{*}$ & RSD \\
\hline 1 & $150 \%$ & 74718 & 74135 & $74427 \pm 412.24$ & 0.55 \\
\hline 2 & $150 \%$ & 74812 & 73556 & $73684 \pm 181.01$ & 0.25 \\
\hline 3 & $150 \%$ & 74520 & 74132 & $74326 \pm 274.35$ & 0.37 \\
\hline
\end{tabular}

SD*-Standard deviation, RSD*-Relative Standard deviation, Number of experiments (n)-3

Table 12: Intraday precision of degradation impurity

\begin{tabular}{|c|c|c|c|c|c|}
\hline \multicolumn{6}{|c|}{$50 \%$ level } \\
\hline Set & Level & Morning & Evening & $\operatorname{mean} \pm \mathrm{SD}^{*}$ & RSD \\
\hline 1 & $50 \%$ & 16381 & 15989 & $16185 \pm 277.18$ & 1.71 \\
\hline 2 & $50 \%$ & 16261 & 15994 & $16128 \pm 188.79$ & 1.17 \\
\hline 3 & $50 \%$ & 16221 & 15931 & $16076 \pm 205.06$ & 1.28 \\
\hline \multicolumn{6}{|c|}{$100 \%$ level } \\
\hline Set & Level & Morning & Evening & $\operatorname{mean} \pm \mathrm{SD}^{*}$ & RSD \\
\hline 1 & $100 \%$ & 32132 & 31818 & $31975 \pm 222.03$ & 0.69 \\
\hline 2 & $100 \%$ & 32331 & 32121 & $32226 \pm 148.49$ & 0.46 \\
\hline 3 & $100 \%$ & 32880 & 32590 & $32735 \pm 205.06$ & 0.63 \\
\hline \multicolumn{6}{|c|}{$150 \%$ level } \\
\hline Set & Level & Morning & Evening & mean $\pm \mathrm{SD}^{*}$ & RSD \\
\hline 1 & $150 \%$ & 51121 & 51159 & $51140 \pm 26.87$ & 0.05 \\
\hline 2 & $150 \%$ & 52310 & 51817 & $52064 \pm 348.60$ & 0.62 \\
\hline 3 & $150 \%$ & 51731 & 51234 & $51483 \pm 287.79$ & 0.56 \\
\hline
\end{tabular}

$\mathrm{SD}^{*}$-Standard deviation, RSD*-Relative standard deviation, Conc*-concentration, Number of experiments (n)-3

\section{Interday precision}

Inter-day precision was performed by injecting stock impurity preparations three times into chromatographic system on 2 different days by maintaining the optimized chromatographic conditions and calculate \% relative standard deviation of retention time and peak areas for macitentan. All impurity area calculated for RSD for Day-1 and Day-2.\%RSD is not more than 5. so method is precise. The results are given in table 13-15.

\section{Robustness}

According to robustness, there is the minor deliberate change made such as in chromatograph parameter with reference of flow rate and column temperature. To observe robustness, $100 \%$ level solution used. Robustness was checked by changing the flow rate and column temperature in the optimized chromatographic condition. This method said to be robust as \% RSD for each studied factor was found to be less than 5 . The results are given in table 16,17, and 18 .

Table 13: Interday precision of MCA-02

\begin{tabular}{|c|c|c|c|c|c|}
\hline \multicolumn{6}{|c|}{$50 \%$ level } \\
\hline Set & Level & Day-1 & Day-2 & mean $\pm \mathrm{SD}^{*}$ & RSD \\
\hline 1 & $50 \%$ & 20432 & 20812 & $20622 \pm 268.70$ & 1.30 \\
\hline 2 & $50 \%$ & 20213 & 20787 & $20500 \pm 405.87$ & 1.98 \\
\hline 3 & $50 \%$ & 20513 & 20013 & $20263 \pm 353.55$ & 1.74 \\
\hline \multicolumn{6}{|c|}{$100 \%$ level } \\
\hline Set & Level & Day-1 & Day-2 & mean $\pm \mathrm{SD}^{*}$ & RSD \\
\hline 1 & $100 \%$ & 36981 & 37130 & $37056 \pm 105.35$ & 0.28 \\
\hline 2 & $100 \%$ & 36607 & 36917 & $36762 \pm 219.20$ & 0.60 \\
\hline 3 & $100 \%$ & 36108 & 36718 & $36413 \pm 431.33$ & 1.18 \\
\hline \multicolumn{6}{|c|}{$150 \%$ level } \\
\hline Set & Level & Day-1 & Day-2 & mean $\pm \mathrm{SD}^{*}$ & RSD \\
\hline 1 & $150 \%$ & 55814 & 56132 & $55973 \pm 224.8$ & 0.40 \\
\hline 2 & $150 \%$ & 56124 & 56338 & $56231 \pm 151.32$ & 0.27 \\
\hline 3 & $150 \%$ & 55754 & 56124 & $55939 \pm 261.62$ & 0.47 \\
\hline
\end{tabular}

$\mathrm{SD}^{*}$-Standard deviation, RSD*-Relative Standard deviation, Number of experiments (n)-3 
Table 14: Interday precision of MCA-01

\begin{tabular}{|c|c|c|c|c|c|}
\hline \multicolumn{6}{|c|}{$50 \%$ Level } \\
\hline Set & Level & Day-1 & Day-2 & mean $\pm \mathrm{SD}^{*}$ & RSD \\
\hline 1 & $50 \%$ & 26013 & 26454 & $26234 \pm 311.83$ & 1.19 \\
\hline 2 & $50 \%$ & 26312 & 26818 & $26565 \pm 375.79$ & 1.35 \\
\hline 3 & $50 \%$ & 26567 & 26121 & $26344 \pm 315.36$ & 1.20 \\
\hline \multicolumn{6}{|c|}{$100 \%$ level } \\
\hline Set & Level & Day-1 & Day-2 & mean $\pm \mathrm{SD}^{*}$ & RSD \\
\hline 1 & $100 \%$ & 52254 & 52535 & $52395 \pm 198.69$ & 0.38 \\
\hline 2 & $100 \%$ & 52312 & 52117 & $52215 \pm 137.88$ & 0.26 \\
\hline 3 & $100 \%$ & 52159 & 52652 & $52406 \pm 348.60$ & 0.67 \\
\hline \multicolumn{6}{|c|}{$150 \%$ level } \\
\hline Set & Level & Day-1 & Day-2 & mean $\pm \mathrm{SD}^{*}$ & RSD \\
\hline 1 & $150 \%$ & 74718 & 74968 & $74843 \pm 176.77$ & 0.24 \\
\hline 2 & $150 \%$ & 74812 & 74528 & $74873 \pm 106.77$ & 0.27 \\
\hline 3 & $150 \%$ & 74520 & 74912 & $74716 \pm 277.18$ & 0.37 \\
\hline
\end{tabular}

$\mathrm{SD}^{*}$-Standard deviation, RSD*-Relative Standard deviation, Number of experiments (n)-3

Table 15: Interday precision of degradation impurity

\begin{tabular}{|c|c|c|c|c|c|}
\hline \multicolumn{6}{|c|}{50 \% Level } \\
\hline Set & Level & Day-1 & Day-2 & mean $\pm \mathrm{SD}^{*}$ & RSD \\
\hline 1 & $50 \%$ & 16381 & 16525 & $16453 \pm 101.82$ & 0.62 \\
\hline 2 & $50 \%$ & 16261 & 16434 & $16348 \pm 122.32$ & 0.75 \\
\hline 3 & $50 \%$ & 16221 & 16623 & $16372 \pm 213.54$ & 1.30 \\
\hline \multicolumn{6}{|c|}{$100 \%$ level } \\
\hline Set & Level & Day-1 & Day-2 & mean $\pm \mathrm{SD}^{*}$ & RSD \\
\hline 1 & $100 \%$ & 32132 & 32722 & $32427 \pm 417.19$ & 1.29 \\
\hline 2 & $100 \%$ & 32331 & 32918 & $32625 \pm 415.07$ & 1.27 \\
\hline 3 & $100 \%$ & 32880 & 32581 & $32731 \pm 211.42$ & 0.65 \\
\hline \multicolumn{6}{|c|}{$150 \%$ level } \\
\hline Set & Level & Day-1 & Day-2 & mean $\pm \mathrm{SD}^{*}$ & RSD \\
\hline 1 & $150 \%$ & 51121 & 51438 & $51280 \pm 224.15$ & 0.44 \\
\hline 2 & $150 \%$ & 52310 & 51912 & $52111 \pm 281.42$ & 0.54 \\
\hline 3 & $150 \%$ & 51731 & 51934 & $51833 \pm 143.54$ & 0.28 \\
\hline
\end{tabular}

$\mathrm{SD}^{*}$-Standard deviation, RSD*-Relative Standard deviation, Number of experiments (n)-3

Table 16: Robustness result of MCA-02

\begin{tabular}{|c|c|c|c|c|c|c|}
\hline Parameter & Change & Area & & & $\%$ Mean recovery $\pm \mathrm{SD}^{*}$ & RSD \\
\hline & & 1 & 2 & 3 & & \\
\hline Flow rate & $1.3 \mathrm{ml}$ & 35312 & 35138 & 35381 & $35842.33 \pm 431.91$ & \multirow{3}{*}{1.20} \\
\hline \multirow[t]{2}{*}{$(\mathrm{ml} / \mathrm{min})$} & $1.5 \mathrm{ml}$ & 36013 & 36133 & 36131 & & \\
\hline & $1.7 \mathrm{ml}$ & 36142 & 36108 & 36223 & & \\
\hline Coloumn & $25^{\circ} \mathrm{C}$ & 36131 & 36150 & 36300 & $35936.22 \pm 352.13$ & \multirow{3}{*}{0.97} \\
\hline \multirow[t]{2}{*}{ temp. } & $30^{\circ} \mathrm{C}$ & 35648 & 35830 & 36101 & & \\
\hline & $35^{\circ} \mathrm{C}$ & 36130 & 36138 & 35998 & & \\
\hline
\end{tabular}

$\mathrm{SD}^{*}$-Standard deviation, RSD*-Relative Standard deviation, Number of experiments (n)-3

Table 17: Robustness result of MCA-01

\begin{tabular}{|c|c|c|c|c|c|c|}
\hline Parameter & Change & Area & & & \% Mean recovery $\pm \mathrm{SD}^{*}$ & RSD \\
\hline Flow Rate & & 1 & 2 & 3 & & \\
\hline \multirow[t]{3}{*}{ (ml/min) } & $1.3 \mathrm{ml}$ & 50324 & 50128 & 50155 & $50907 \pm 546.83$ & \\
\hline & $1.5 \mathrm{ml}$ & 51312 & 50998 & 51212 & & 1.07 \\
\hline & $1.7 \mathrm{ml}$ & 51502 & 51304 & 51228 & & \\
\hline Coloumn & $25^{\circ} \mathrm{C}$ & 51034 & 50938 & 50868 & $51267.67 \pm 258.33$ & \\
\hline \multirow[t]{2}{*}{ Temp. } & $30^{\circ} \mathrm{C}$ & 51341 & 51554 & 51344 & & 0.50 \\
\hline & $35^{\circ} \mathrm{C}$ & 51334 & 51558 & 51438 & & \\
\hline
\end{tabular}

$\mathrm{SD}^{*}$-Standard deviation, $\mathrm{RSD}^{*}$-relative standard deviation, number of experiments (n)-3

Table 18: Robustness result of degradation impurity

\begin{tabular}{|c|c|c|c|c|c|c|}
\hline Parameter & Change & Area & & & \%Mean recovery \pm SD $^{*}$ & RSD \\
\hline Flow rate & & 1 & 2 & 3 & \multirow{4}{*}{$35278.67 \pm 357.68$} & \multirow{3}{*}{1.01} \\
\hline \multirow[t]{3}{*}{$(\mathrm{ml} / \mathrm{min})$} & $1.3 \mathrm{ml}$ & 33133 & 32734 & 33187 & & \\
\hline & $1.5 \mathrm{ml}$ & 33077 & 33412 & 33132 & & \\
\hline & $1.7 \mathrm{ml}$ & 33814 & 33581 & 33781 & & \multirow{4}{*}{0.53} \\
\hline Column & $25^{\circ} \mathrm{C}$ & 32812 & 33018 & 32918 & \multirow[t]{3}{*}{$33072.44 \pm 176.45$} & \\
\hline \multirow[t]{2}{*}{ temp. } & $30^{\circ} \mathrm{C}$ & 33118 & 33418 & 33216 & & \\
\hline & $35^{\circ} \mathrm{C}$ & 33141 & 32998 & 33013 & & \\
\hline
\end{tabular}

$\mathrm{SD}^{*}$-Standard deviation, $\mathrm{RSD}^{*}$-relative standard deviation, Number of experiments (n)-3 


\section{CONCLUSION}

All the parameters and results were found within the acceptance limit as given in the validation protocol. So we can conclude that the developed RP-HPLC Method was selective, specific, sensitive, linear, accurate, precise, and robust. Therefore the method is found to be specific for macitentan's related substances with good resolution. It can be applied to the forced degradation study. So the proposed method can be used in the pharmaceutical analysis for Forced degradation study and routine quality control samples of macitentan Tablets.

\section{ACKNOWLEDGEMENT}

The authors are thankful to ZYDUS CADILA HEALTH CARE, Moraiya, Ahmedabad, for providing all the facilities to complete the research work and for providing Macitentan and Impurities as gift samples.

\section{AUTHORS CONTRIBUTIONS}

All the author have contributed equally

\section{CONFLICT OF INTERESTS}

Declared none

\section{REFERENCES}

1. National Center for Biotechnology Information. PubChem Compound Database; CID 16004692 Available from: http. [Last accessed on 20 Mar 2018]

2. Humbert M, Sitbon O, Simonneau G. Treatment of pulmonary arterial hypertension. N Engl J Med 2004;351:1425.

3. Satoskar RS, Bhandarkar SD, Ainapure SS. Pharmacology and pharmacotherapeutics. 16th ed. Mumbai: Popular prakashan; 2003. p. 401.

4. Chopra S, Badyal DK, Baby PC, Cherian D. Pulmonary arterial hypertension-advances in pathophysiology and management. Indian J Pharmacol 2012;44:4-11.
5. Patel MM, Patel CJ, Mishra S. Development and stability indicating chromatographic method for simultaneous of sacubitril and valsartan in pharmaceutical dosage form. Int J Appl Pharm 2017;9:1-8.

6. Ahmed M, Deepak BM, Shetty SA, Vijaya KC, Aradhya. Development andvalidation of first order derivative Spectrophotometric method for estimation ofmacitentan in bulk and tablet dosage form. Int J Universal Pharm BioSci 2015;4:269-75.

7. Ahmed M, Deepak BM, Shetty SA, Kuppast IJ, Anilkumar SM, MC Ravi. RP-HPLC method development and validation for estimation of macitentanintablet dosage form. J Pharm Pharm Sci 2014;4:881.

8. Lixiu Yu, Ying Zhou. Simultaneous determination of macitentan and its metabolite in human plasma by liquid chromatography tandem mass spectrometry J. Chromatography B 2015;1002:358.

9. D Lakshmi, P Hitesh Kumar, M Praveen, Reddy Praksh TVS, G Manish, J Jayachandran. Quality by design based HPLC method development of macitentan and its related compound in bulk drugs. J Pharma Drug Deilvery 2016;5:1.

10. Quality Assurance of Pharmaceuticals, A compendium of guidelines and related materials; WHO, Geneva; 1997. p. 119:24.

11. ICH Q3A and Q3B (R2). Impurities in New Drug Substances and Drug Products, 2006. International Conference on Harmonization (ICH) (2005) Harmonized Tripartite Guideline on, Topic Q2(R1), Validation of Analytical Procedures: Text and Methodology, Geneva; 2005;1:13.

12. ICH Q2 (R1) Validation of Analytical Procedure; 2005. p. 14

13. Ahmed M, Deepak BM, Shetty SA, Kuppast IJ, Anilkumar SM, Ravi MC. RP-HPLC method development and validation for estimation of macitentan in tablet dosage form. J Pharm Pharma Sci 2015;4:887. 